Review

\title{
The Chemical Composition and Biological Properties of Coconut (Cocos nucifera L.) Water
}

\author{
Jean W. H. Yong, Liya Ge, Yan Fei Ng and Swee Ngin Tan* \\ Natural Sciences and Science Education Academic Group, Nanyang Technological University, \\ 1 Nanyang Walk, 637616 Singapore \\ * Author to whom correspondence should be addressed; E-Mail: sweengin.tan@nie.edu.sg; \\ Tel.: +65-6790 3810; Fax: +65-6896 9432 .
}

Received: 3 November 2009; in revised form: 3 December 2009 / Accepted: 8 December 2009 / Published: 9 December 2009

\begin{abstract}
Coconut water (coconut liquid endosperm), with its many applications, is one of the world's most versatile natural product. This refreshing beverage is consumed worldwide as it is nutritious and beneficial for health. There is increasing scientific evidence that supports the role of coconut water in health and medicinal applications. Coconut water is traditionally used as a growth supplement in plant tissue culture/micropropagation. The wide applications of coconut water can be justified by its unique chemical composition of sugars, vitamins, minerals, amino acids and phytohormones. This review attempts to summarise and evaluate the chemical composition and biological properties of coconut water.
\end{abstract}

Keywords: coconut water; phytohormone; auxin; cytokinin; gibberellin; inorganic ion; vitamin

\section{Introduction}

The coconut (Cocos nucifera L.) is an important fruit tree in the tropical regions and the fruit can be made into a variety of foods and beverages (Figure 1). The edible part of the coconut fruit (coconut meat and coconut water) is the endosperm tissue. Endosperm tissues undergo one of three main modes of development, which are the nuclear, cellular and helobial modes [1] and the development of coconut endosperm belongs to the nuclear mode. Initially, the endosperm is a liquid containing free nuclei generated by a process, in which the primary endosperm nucleus undergoes several cycles of 
division without cytokinesis (the process in which the cytoplasm of a single eukaryotic cell is divided to form two daughter cells). Cytokinesis then occurs, progressing from the periphery towards the center, thus forming the cellular endosperm layer. At first, the cellular endosperm is translucent and jelly-like, but it later hardens at maturity to become white flesh (coconut meat). Unlike the endosperms of other plants (e.g., wheat and corn), the cellularization process in a coconut fruit does not fill up the entire embryo sac cavity, but instead leaves the cavity solution-filled. This solution is commonly known as coconut water and it is of cytoplasmic origin [2]. Nutrients from coconut water are obtained from the seed apoplasm (surrounding cell wall) and are transported symplasmically (through plasmodemata, which is the connection between cytoplasms of adjacent cells) into the endosperm [3].

Figure 1. Foods and beverages made from coconut: (a) coconut milk and dried coconut milk powder; (b) canned coconut water/juice and trimmed young coconuts.
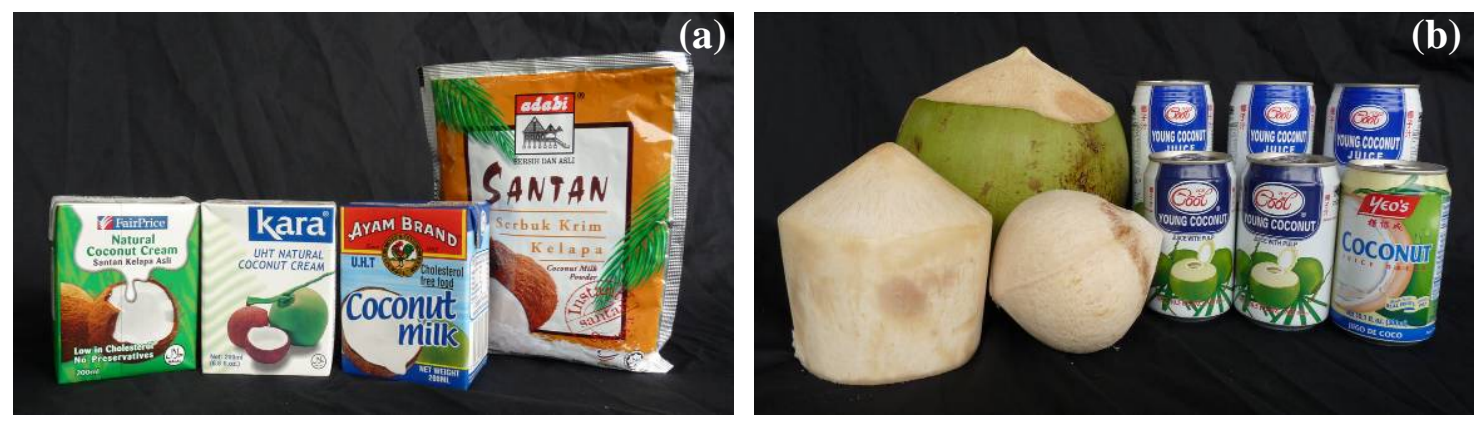

Coconut water should not be confused with coconut milk (Figure 1a), although some studies have used the two terms interchangeably (e.g., [4-5]). The aqueous part of the coconut endosperm is termed coconut water (Figure 1b), whereas coconut milk, also known as "santan" in Malaysia and Indonesia, and "gata" in the Philippines (Figure 1a), refers to the liquid products obtained by grating the solid endosperm, with or without addition of water [6]. Coconut water is served directly as a beverage to quench thirst (Figure 1b), while coconut milk is usually used as a food ingredient in various traditional cooking recipes (Figure 1a). The main components of coconut milk are water (ca. 50\%), fat and protein [7], whereas coconut water contains mainly water (ca. 94\%, Table 1). Unlike coconut water, coconut milk, which is the source of coconut oil, is generally not used in plant tissue culture medium formulations [8].

Compared to coconut water, there are only limited studies on the aqueous extract of coconut solid endosperm (coconut meat or copra). Mariat et al. used coconut meat extract in orchid tissue culture to study its effects on orchid seed germination [9]. Subsequently, Mauney et al. purified a growth factor from the aqueous extract of coconut meat which was found to be very potent in promoting growth of tissue cultured plants [10]. Another group, Shaw and Srivastava demonstrated the presence of purinelike substances in coconut meat extract [11]. The purine-like substances were able to delay senescence (the process of ageing in plants) in detached cereal leaves, which exhibited similar known physiological effects of cytokinins. Zakaria et al. showed that the aqueous extract of coconut meat exhibited anti-inflammatory and wound healing properties when tested on mice [12]. 
Table 1. Chemical composition of coconut water [20,29-31].

\begin{tabular}{|c|c|c|c|c|c|c|c|c|}
\hline \multirow{5}{*}{$\begin{array}{c}\text { Source information } \\
\text { Coconut type } \\
\text { Average Weight of Coconut (g) } \\
\text { Age of coconut } \\
\text { Source of coconut } \\
\end{array}$} & \multirow[t]{5}{*}{ [20] } & \multirow{5}{*}{$\begin{array}{c}\text { [31] } \\
\text { young } \\
206 \text { (water) }\end{array}$} & \multicolumn{4}{|c|}{ [29] } & \multicolumn{2}{|c|}{ [30] } \\
\hline & & & $\begin{array}{l}\text { young } \\
\text { green }\end{array}$ & $\begin{array}{c}\text { mature } \\
\text { green }\end{array}$ & & $\begin{array}{c}\text { mature } \\
\text { (autoclaved) }\end{array}$ & & mature \\
\hline & & & & & & & 565 & 393 \\
\hline & & & & & & & 6 months & 12 months \\
\hline & & & \multicolumn{4}{|c|}{ Deerfield Beach, FL } & & \\
\hline Proximates & & $(g / 100 g)$ & & & & & \multicolumn{2}{|c|}{$(g / 100 g)$} \\
\hline Water & & 94.99 & & & & & 94.18 & 94.45 \\
\hline Dry & & 5.01 & & & & & 5.82 & 5.55 \\
\hline Energy value & & $19 \mathrm{kcal}(79 \mathrm{~kJ})$ & & & & & & \\
\hline Protein & & 0.72 & & & & & 0.12 & 0.52 \\
\hline Total lipid (fat) & & 0.2 & & & & & 0.07 & 0.15 \\
\hline Ash & & 0.39 & & & & & 0.87 & 0.47 \\
\hline Carbohydrate, by difference & & 3.71 & & & & & 4.76 & 4.41 \\
\hline Fiber, total dietary & & 1.1 & & & & & $\mathrm{ND}^{*}$ & $\mathrm{ND}^{*}$ \\
\hline Sugars & $(m g / m L)$ & $(g / 100 g)$ & \multicolumn{4}{|c|}{$(m g / m L)$} & \multicolumn{2}{|c|}{$(g / 100 g)$} \\
\hline Total & & 2.61 & 9.16 & 21.68 & 13.87 & 15.20 & 5.23 & 3.42 \\
\hline Sucrose & 9.18 & & 0.93 & 9.18 & 8.90 & 10.70 & 0.06 & 0.51 \\
\hline Glucose & 7.25 & & 3.93 & 7.25 & 2.46 & 2.02 & 2.61 & 1.48 \\
\hline Fructose & 5.25 & & 4.30 & 5.25 & 2.51 & 2.48 & 2.55 & 1.43 \\
\hline Sugar alcohols & Present $^{\mathrm{a}}$ & & & $(m g / L)$ & & & & \\
\hline Mannitol & 0.8 & & & 0.80 & & & & \\
\hline Sorbitol & $15^{\mathrm{d}}$ & & & 15.00 & & & & \\
\hline Myo-inositol & 0.01 & & & 0.01 & & & & \\
\hline Scyllo-inositol & 0.05 & & & 0.05 & & & & \\
\hline
\end{tabular}


Table 1. Cont.

\begin{tabular}{|c|c|c|c|c|c|}
\hline Inorganic ions & $(\mathrm{mg} / 100 \mathrm{~g})$ & $(m g / 100 g)$ & $(\mathrm{mg} / 100 \mathrm{~g})$ & \multicolumn{2}{|c|}{$(m g / 100 g)$} \\
\hline Calcium, $\mathrm{Ca}$ & & 24 & & 27.35 & 31.64 \\
\hline Iron, $\mathrm{Fe}$ & 0.01 & 0.29 & 0.01 & 0.02 & 0.02 \\
\hline Magnesium, $\mathrm{Mg}$ & 30 & 25 & 30 & 6.40 & 9.44 \\
\hline Phosphorus, $\mathrm{P}$ & 37 & 20 & 37 & 4.66 & 12.77 \\
\hline Potassium, K & 312 & 250 & 312 & 203.70 & 257.52 \\
\hline Sodium, $\mathrm{Na}$ & 105 & 105 & 105 & 1.75 & 16.10 \\
\hline Zinc, Zn & & 0.1 & & 0.07 & 0.02 \\
\hline Copper, $\mathrm{Cu}$ & 0.04 & 0.04 & 0.04 & 0.01 & 0.03 \\
\hline Manganese, Mn & & 0.142 & & 0.12 & 0.08 \\
\hline Selenium, Se & & 0.001 & & & \\
\hline Chlorine, $\mathrm{Cl}$ & 183 & & 183 & & \\
\hline Sulfur, S & 24 & & 24 & 0.58 & \\
\hline Aluminium, Al & & & & 0.07 & 0.06 \\
\hline Boron, B & & & & 0.05 & 0.08 \\
\hline Vitamins & $(m g / m L)$ & $(m g / 100 g)$ & $(m g / L)$ & $(\mathrm{mg} / 1$ & \\
\hline Vitamin C, total ascorbic acid & & 2.4 & & 7.41 & 7.08 \\
\hline Thiamin (B1) & & 0.03 & Trace & Trace & 0.01 \\
\hline Riboflavin (B2) & & 0.057 & 0.01 & 0.01 & 0.01 \\
\hline Niacin (B3) & & 0.08 & 0.64 & $\mathrm{ND}^{*}$ & $\mathrm{ND}^{*}$ \\
\hline Pantothenic acid (B5) & 0.52 & 0.043 & 0.52 & & \\
\hline Pyridoxine (B6) & & 0.032 & Trace & ND* & ND* \\
\hline Folate, total & & 0.03 & & & \\
\hline Folic acid & 0.003 & 0 & 0.003 & & \\
\hline Folate, food & & 0.003 & & & \\
\hline Folate, Dietary Folate Equivalent & & & & & \\
\hline$(\mathrm{DFE})$ & & $3\left(\mu \mathrm{g} \_\mathrm{DFE}\right.$ & & & \\
\hline Biotin & 0.02 & & 0.02 & & \\
\hline Nicotinic acid (Niacin) & 0.64 & & 0.64 & & \\
\hline
\end{tabular}


Table 1. Cont.

\begin{tabular}{|c|c|c|c|c|c|c|c|c|}
\hline Lipids & & $(g / 100 g)$ & & & & & \multicolumn{2}{|c|}{$(g / 100 g)$} \\
\hline Total & & 0.2 & & & & & 0.0733 & 0.1482 \\
\hline Fatty acids, total saturated & & 0.176 & & & & & 0.03 & 0.1 \\
\hline 6:00 & & 0.001 & & & & & & \\
\hline $8: 00$ & & 0.014 & & & & & $\mathrm{ND}^{*}$ & $\mathrm{ND}^{*}$ \\
\hline 10:00 & & 0.011 & & & & & 0.0007 & 0.0028 \\
\hline 12:00 & & 0.088 & & & & & 0.002 & 0.0274 \\
\hline 14:00 & & 0.035 & & & & & 0.0023 & 0.019 \\
\hline 16:00 & & 0.017 & & & & & 0.0219 & 0.032 \\
\hline 17:00 & & & & & & & 0.0009 & 0.0016 \\
\hline 18:00 & & 0.01 & & & & & 0.0039 & 0.0108 \\
\hline 20:00 & & & & & & & 0.0016 & 0.0033 \\
\hline Fatty acids, total monounsaturated & & 0.008 & & & & & 0.03 & 0.02 \\
\hline 16:1 undifferentiated & & 0 & & & & & 0.0011 & 0.0007 \\
\hline 18:1 undifferentiated & & 0.008 & & & & & 0.0194 & 0.015 \\
\hline 20:1 undifferentiated & & & & & & & 0.0049 & 0.0019 \\
\hline 22:1 undifferentiated & & & & & & & 0.0011 & 0.0023 \\
\hline Fatty acids, total polyunsaturated & & 0.002 & & & & & 0.0128 & 0.0054 \\
\hline 18:2 n-6undifferentiated & & 0.002 & & & & & 0.0114 & 0.0032 \\
\hline $20: 4 n-6$ & & & & & & & 0.0014 & 0.0022 \\
\hline Amino acids & $(\mu g / m L)$ & $(g / 100 g)$ & & $(\mu g)$ & & & (mg/g defa & \\
\hline Alanine & 312 & 0.037 & 16.40 & 127.30 & 177.10 & 198.00 & 1.13 & 3.88 \\
\hline$\beta$-Alanine & 12 & & & & & & & \\
\hline$\gamma$-Aminobutyric acid & 820 & & 1.90 & 34.60 & 168.80 & 173.20 & & \\
\hline Arginine & 133 & 0.118 & 14.70 & 25.60 & 16.80 & 20.70 & 0.13 & 0.81 \\
\hline Asparagine and glutamine & ca. 60 & & & & & & & \\
\hline Aspartic acid & 65 & 0.07 & 11.30 & 35.90 & 5.40 & 11.40 & 1.60 & 0.76 \\
\hline Asparagine & & & 17.10 & 10.10 & 10.40 & 25.30 & & \\
\hline Cystine & $0.97-1.17^{b}$ & 0.014 & & & & & 0.00 & 0.00 \\
\hline
\end{tabular}


Table 1. Cont.

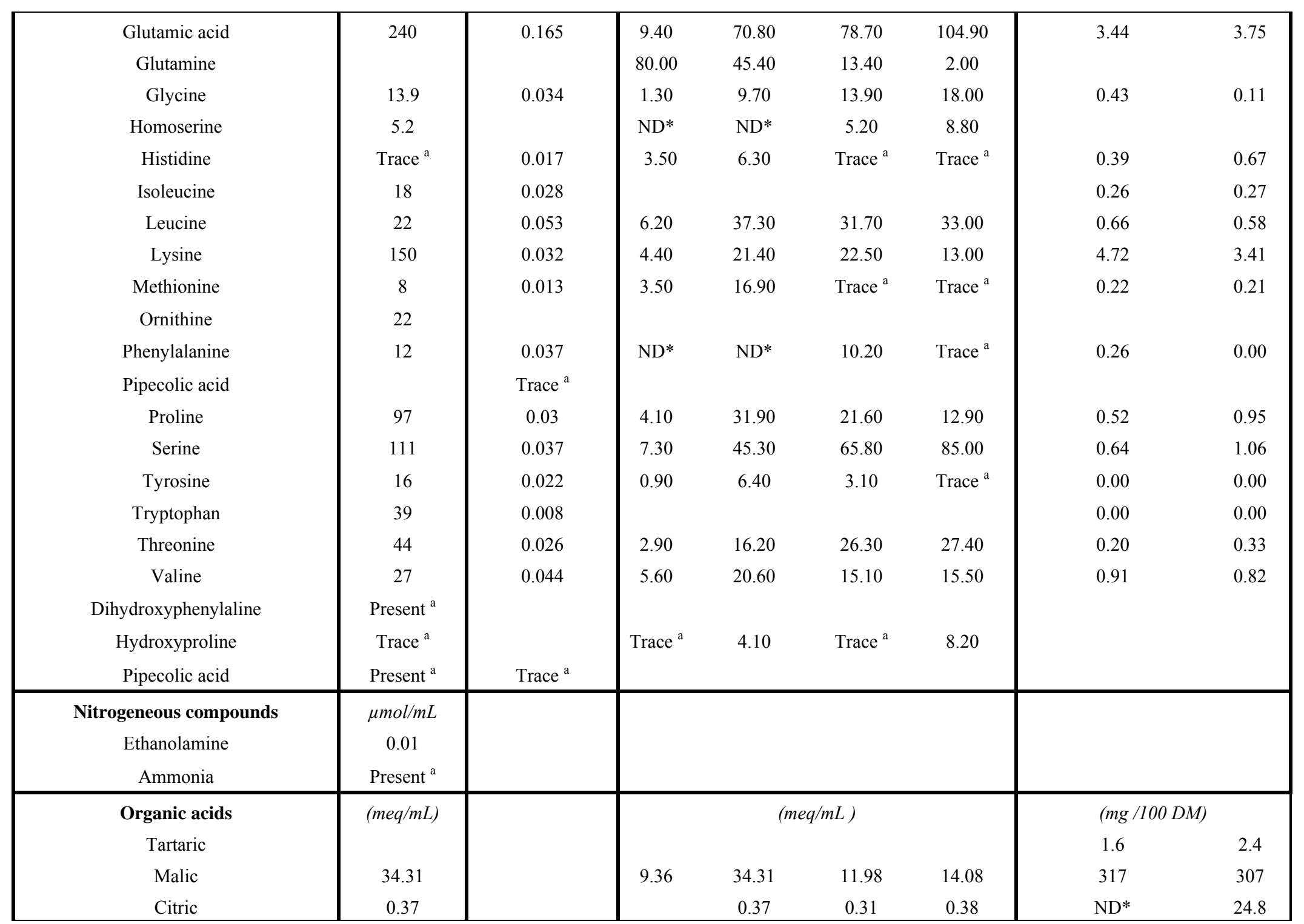


Table 1. Cont.

\begin{tabular}{|c|c|c|c|c|c|c|c|}
\hline $\begin{array}{c}\text { Acetic } \\
\text { Pyridoline } \\
\text { Succinic } \\
\text { Shikimic and quinic acids, etc. }\end{array}$ & $\begin{array}{c}0.39 \mathrm{mg} / \mathrm{mL} \\
0.57 \\
\end{array}$ & 0.43 & 0.39 & $\begin{array}{l}0.18 \\
0.28\end{array}$ & $\begin{array}{l}0.27 \\
0.18\end{array}$ & $\mathrm{ND}^{*}$ & 1.3 \\
\hline $\begin{array}{c}\text { Enzymes } \\
\text { Acid phosphatase } \\
\text { Catalase } \\
\text { Dehydrogenase } \\
\text { Diastase } \\
\text { Peroxidase } \\
\text { RNA polymerases }\end{array}$ & $\begin{array}{l}\text { Present }{ }^{a} \\
\text { Present }^{\text {a }} \\
\text { Present }^{\text {a }} \\
\text { Present }^{\text {a }} \\
\text { Present }^{\text {a }} \\
\text { Present }^{\text {a }}\end{array}$ & & & & & & \\
\hline $\begin{array}{c}\text { Phytohormones } \\
\text { Auxin } \\
\text { 1,3- Diphenylurea } \\
\text { Cytokinin } \\
\end{array}$ & $\begin{array}{c}(\mathrm{mg} / \mathrm{mL}) \\
0.07 \\
\text { Present }^{\mathrm{a}} \\
\end{array}$ & & $\begin{array}{c}(m g / L) \\
0.07 \\
5.8\end{array}$ & & & & \\
\hline $\begin{array}{l}\text { Miscellaneous } \\
\text { Leucoanthocyanin } \\
\text { Phyllococosine } \\
\end{array}$ & $\begin{array}{l}\text { Present }{ }^{a} \\
\text { Present }{ }^{a}\end{array}$ & & & & & & \\
\hline $\begin{array}{c}\text { Chemical properties } \\
\text { pH }\end{array}$ & & $\begin{array}{c}4.6 \text { to } \\
5.6\end{array}$ & & & & $4.7 \pm 0.1$ & $5.2 \pm 0.1$ \\
\hline
\end{tabular}

* $\mathrm{ND}=$ Non detectable; ${ }^{\mathrm{a}}$ No units given; ${ }^{\mathrm{b}}$ Units: $\mathrm{g} / 100 \mathrm{~g}$ dried protein; ${ }^{\mathrm{d}}$ Units: $\mathrm{mg} / \mathrm{mL} ;{ }^{\mathrm{e}}$ Due to contamination. 
Conversely, coconut water has been extensively studied since its introduction to the scientific community in the 1940s. In its natural form, it is a refreshing and nutritious beverage which is widely consumed due to its beneficial properties to health, some of which are based on cultural/traditional beliefs $[2,5-8,13-15]$. It is also believed that coconut water could be used as an important alternative for oral rehydration and even so for intravenous hydration of patients in remote regions [13]. Coconut water may also offer protection against myocardial infarction [15]. Interestingly, a study has shown that regular consumption of either coconut water or mauby (a liquid extracted from the bark of the mauby tree, Colubrina arborescens), or particularly, a mixture of them, is effective in bringing about the control of hypertension [16].

Apart from that, coconut water is widely used in the plant tissue culture industry [17-20]. The extensive use of coconut water as a growth-promoting component in tissue culture medium formulation can be traced back to more than half a century ago, when Overbeek et al. first introduced coconut water as a new component of the nutrient medium for callus cultures in 1941 [17]. From a scientific viewpoint, the addition of coconut water to the medium is rather unsatisfactory, as it precludes the possibility for investigating the effects of individual components of the medium with any degree of accuracy. The question of which components cause the growth stimulation arose immediately. Besides its nutritional role, coconut water also appears to have growth regulatory properties, e.g., cytokinin-type activity [8].

Some of the most significant and useful components in coconut water are cytokinins, which are a class of phytohormones [21]. The first cytokinin, $N^{6}$-furfuryladenine (kinetin) was isolated from an autoclaved sample of herring sperm DNA in 1955 [22-23]. In 1963, Letham isolated trans-zeatin, the first naturally-occurring cytokinin, from a plant source (unripe corn seeds) [24]. In addition to various plant-related functions, it was also found that some cytokinins (e.g., kinetin and trans-zeatin) showed significant anti-ageing, anti-carcinogenic, and anti-thrombotic effects [25-26].

Furthermore, micronutrients (nutrients needed in small quantities) such as inorganic ions and vitamins in coconut water play a vital role in aiding the human body antioxidant system [27]. Hypermetabolism gives rise to an increased production of reactive oxygen species (or free radicals), as a result of increased oxidative metabolism. Such increase in free radicals will cause oxidative damage to the various components of the human cell, especially the polyunsaturated fatty acids in the cell membrane, or to the nucleic acids in the nucleus [27]. Fortunately, living organisms have well developed antioxidant systems to neutralize the most detrimental effects of these oxidizing species. Micronutrients have important functions in this aspect. For example, they act directly to quench free radicals by donating electrons, or indirectly as a part of metallo enzymes (a diverse class of enzymes that require a catalytic metal ion for their biological activity) such as glutathione peroxidase (selenium) or superoxide dismutase (zinc, copper) to catalyse the removal of oxidizing species [28].

Other components found in coconut water include sugars, sugar alcohols, lipids, amino acids, nitrogenous compounds, organic acids and enzymes [20,29-31], and they play different functional roles in plant and human systems due to their distinct chemical properties. The myriad of compounds, both known and unknown, provide coconut water with the special biological properties that is known to the typical layman. In this paper, we will present a summary on the chemical composition of the known compounds in coconut water. 


\section{Chemical Composition of Coconut Water}

\subsection{Phytohormones}

Phytohormones are a group of naturally occurring organic compounds that play crucial roles in regulating plant growth in a wide range of developmental processes. Initially, the term phytohormone was synonymous with auxin. Later on, the other plant growth regulators such as gibberellins (GAs), ethylene, cytokinins, and abscisic acid (ABA) were categorized together with auxins as the "classical five" hormones [21]. Coconut water contains auxin, various cytokinins, GAs and ABA (Table 2) $[4,32-35]$.

Table 2. Naturally-occurring phytohormones unequivocally identified in coconut water.

\begin{tabular}{|c|c|c|c|}
\hline Source information & [4] & [32-34] & [35] \\
\hline Coconut type & & young green & mature* \\
\hline Auxin & & $\mathrm{nM}$ & $\mu \mathrm{g} \mathrm{mL}^{-1}$ \\
\hline indole-3-acetic acid & & 150.6 & $\begin{array}{l}0.25 \pm 0.03 \\
0.75 \pm 0.04 \\
1.46 \pm 0.13 \\
0.71 \pm 0.12 \\
0.78 \pm 0.10\end{array}$ \\
\hline \multicolumn{4}{|l|}{ Cytokinins } \\
\hline $\begin{array}{c}N^{6} \text {-isopentenyladenine } \\
\text { dihydrozeatin } \\
\text { trans-zeatin } \\
\text { kinetin } \\
\text { ortho-topolin } \\
\text { dihydrozeatin } O \text {-glucoside } \\
\text { trans-zeatin } O \text {-glucoside } \\
\text { trans-zeatin riboside } \\
\text { kinetin riboside } \\
\text { trans-zeatin riboside-5'- } \\
\text { monophosphate }\end{array}$ & & $\begin{array}{l}0.26 \\
0.14 \\
0.09 \\
0.31 \\
3.29 \\
46.6 \\
48.7 \\
76.2 \\
0.33 \\
10.2\end{array}$ & \\
\hline $\begin{array}{c}\text { 14-O- }(3-O-[\beta \text {-D-galacto- } \\
\text { pyranosyl- }(1 \rightarrow 2)-\alpha-\mathrm{D}- \\
\text { galactopyranosyl- }(1 \rightarrow 3) \text { - } \\
\alpha \text {-L-arabinofuranosyl]-4-O- } \\
(\alpha \text {-L-arabinofuranosyl)- } \beta \text { - } \\
\text { D-galactopyranosyl)-trans- } \\
\text { zeatin riboside }\end{array}$ & Present & & \\
\hline \multicolumn{4}{|l|}{ Gibberellins } \\
\hline $\begin{array}{c}\text { gibberellin } 1 \\
\text { gibberellin } 3 \\
\text { Auxin }\end{array}$ & & $\begin{array}{l}16.7 \\
37.8\end{array}$ & \\
\hline indole-3-acetic acid & & 150.6 & \\
\hline
\end{tabular}


Table 2. Cont.

\begin{tabular}{|c|c|c|c|}
\hline & & $0.010 \pm 0.002$ \\
& & & ND \\
Abscisic acid & 65.5 & $0.023 \pm 0.002$ \\
& & & $0.061 \pm 0.019$ \\
& & & $0.071 \pm 0.018$ \\
\hline \multirow{3}{*}{ Salicylic acid } & & & $1.01 \pm 0.10$ \\
& & & $0.67 \pm 0.04$ \\
& & & $1.03 \pm 0.12$ \\
& & & $1.79 \pm 0.21$ \\
& & & $1.22 \pm 0.07$ \\
\hline
\end{tabular}

* Five coconut water samples were analysed.

\subsubsection{Auxin}

Coconut water contains indole-3-acetic acid (IAA), the primary auxin in plants [34,35]. IAA is a weak acid $(\mathrm{pKa}=4.75)$ that is synthesized in the meristematic regions located at the shoot apex and subsequently transported to the root tip in plants [36]. For many years, tryptophan was assumed to be the precursor of IAA and this was later confirmed using experiments involving seedlings of Phaseolus vulgaris subjected to stable isotope labeling studies [37]. IAA occurs not only in the free form, but is also conjugated to various amino acids, peptides, or carbohydrates. These IAA conjugates are biologically inactive and appear to be the IAA storage forms in seeds and are probably involved in hormonal homeostasis [38].

Auxin is implicated in many regulatory processes in plants especially those relating to plant growth and development [39-40]. Auxin functions in the relay of environmental signals such as light and gravity, the regulation of branching processes in shoots and roots, and as discovered more recently, the patterned differentiation of cells in meristems and immature organs [39]. Undoubtedly, it is a versatile spatial-temporal signal. Auxin transport generates auxin concentration maxima and gradients within tissues that are instrumental in the diverse regulation of various plant developmental processes, including embryogenesis, organogenesis, vascular tissue formation and tropisms. The unique signalmolecule transport mechanism of auxin to a large extent underlies the remarkable developmental plasticity of plants that allows their growth and architecture to fit the environment changing [41].

\subsubsection{Cytokinins}

Cytokinins, being able to induce plant cell division, were discovered in the 1950s [22,42-43]. Natural cytokinins are $N^{6}$-substituted adenine derivatives with various substituted groups, and the physicochemical behaviour of cytokinins is a function of side chain(s), sugar, phosphate and degree of purine ring and/or side chain modification [43]. The auxin-cytokinin hypothesis predicted that cytokinins, together with auxins, play an essential role in plant morphogenesis by controlling the formation of roots and shoots and moderating their relative growth [42]. Cytokinins are a class of phytohormones that exert various roles in the different aspects of plant growth and development, e.g., cell division, formation and activity of shoot meristems, induction of photosynthesis gene expression, 
leaf senescence, nutrient mobilization, seed germination, root growth and stress response [22,42-46]. Evidently, cytokinin-deficient plants generally develop stunted shoots with smaller apical meristems. The plastochrone of these cytokinin-deficient plants is prolonged, and leaf cell production is only 3$4 \%$ of wild type plants (with normal cytokinin metabolism), indicating an absolute role of cytokinins in leaf growth. Cytokinins are required during leaf formation, both to drive the cell division cycle at normal rates and to obtain the required number of divisions in order to produce a normal leaf size [42]. In addition, cytokinins are also involved in promoting the transition from undifferentiated stem cells to differentiated tissues [47]. Unlike the growth-promoting role of cytokinins in the shoot apical meristem, cytokinins have a negative regulatory function in root growth whereby it suppresses cell division in plant roots [42].

Furthermore, cytokinins play an important role in retarding or even reversing leaf senescence [44-46]. Gan and Amasino reported on the three approaches used to investigate the inhibitory role of the cytokinins in plant senescence: the external application of cytokinins, the measurement of endogenous cytokinin levels before and during senescence, and the manipulation of endogenous cytokinin production in transgenic plants. However, externally applied cytokinins were not always effective in blocking the senescence of excised leaves. The effect of cytokinins on senescence can also vary under different experimental conditions. These studies revealed an inverse correlation between cytokinin levels and the progression of senescence in a variety of tissues and plant species. Cytokinins can interfere with senescence in detached tissues of dicotyledons and monocotyledons but are often less effective in attached tissues. In addition, cytokinin levels, as well as the capacity to synthesize cytokinin, decline with the progression of leaf senescence [48].

Coconut water is an important additive in the tissue culture media of several plants, including orchids and traditional Chinese medicinal herbs. The cytokinins found in coconut water support cell division, and thus promote rapid growth. They are mostly used to propagate protocorm-like bodies of orchids in plant industries [49]. However, it should be noted that cytokinins cannot completely substitute coconut water's effects. This is due to the presence of other phytohormones (such as auxin and gibberellins [33-35]) or even undefined chemical components which may exert synergistic effects with cytokinins. One advantage of coconut water is that it results in considerable plant cell proliferation without increasing the number of undesirable mutations [20]. Coconut water contains various cytokinins (Table 2). For this review, only kinetin, trans-zeatin and their derivatives will be discussed in greater detail as they are known to possess medicinal values [26,50-52].

\section{$N^{6}$-Furfuryladenine (Kinetin)}

The first cytokinin, kinetin was discovered by Miller et al. in Wisconsin. It was a degradation product of herring sperm DNA and was found to be able to promote cell division in plants [22-23]. Kinetin was previously assumed to be an unnatural and synthetic compound, until in 1996 Barciszewski et al. detected it in freshly extracted cellular DNA from human cells and in plant cell extracts [53]. And recently, Ge et al. identified kinetin and kinetin riboside from coconut water [54].

Being one of the cytokinins, kinetin has the effects on the plant developmental processes that could be influenced by cytokinins, such as leaf expansion and seed germination. Most importantly, kinetin is well known for its ability to retard senescence in plants [48,55-58]. 
Recently, its strong anti-ageing effects on human skin cells and fruitflies (Zaprionus paravittiger) were also reported [26,59-60]. Kinetin slowed down the ageing processes, and prolonged the lifespan of fruitflies, which was mainly due to a reduction in age-specific death rates throughout the adult lifespan [59]. In addition, kinetin enhanced cell division and led to fewer cells being arrested at the $\mathrm{G}_{0} / \mathrm{G}_{1}$ phase, thus delaying the ageing of endothelial cells and increasing cell proliferation and metabolic capacity [61]. Most importantly, the anti-ageing effects of kinetin did not increase the cell culture lifespan in terms of maximum proliferative capacity in vitro, in contrast to many other antiageing factors which are known to promote carcinogenesis under certain conditions [26,62]. Kinetin was shown to delay the onset of several cellular and biochemical characteristics associated to cellular ageing in human skin fibroblast cultures [26]. Based on the results obtained from studies on the antiageing effects of kinetin on human skin cells [63], skin care products containing kinetin were subsequently developed to treat photo-damaged skin [64].

Recent research evidence revealed that oxidative DNA damage plays an important role in cancer development and that dietary antioxidants can provide effective protection against oxidative damage [65]. Kinetin was shown to act as a strong antioxidant both under in vitro and in vivo conditions. A study done by Olsen et al. demonstrated that kinetin protected DNA from oxidative damage mediated by the Fenton reaction. Kinetin inhibited the formation of 8-oxo-2'deoxyguanosine, which is a common marker of oxidative damage in DNA [66]. In addition, kinetin was found to inhibit oxidative and glycoxidative protein damage generated in vitro [67]. The anti-oxidative properties of kinetin suggested that it may also prevent the oxidative damage of unsaturated fatty acids located within the cell membranes [68].

Kinetin riboside exhibited a cytotoxic effect on plant crown-gall cells [69]. Its anti-proliferative and apoptogenic effects against human cancer cells were also well documented. Studies on the inhibition of kinetin and kinetin riboside on the growth of human fibroblasts, epithelium and mammary carcinoma were conducted [70-72]. A recent study revealed that kinetin riboside could induce apoptosis in HeLa and mouse melanoma B16F-10 cells [50]. Moreover, kinetin riboside also has significant effects on inhibiting the growth of human heptamoa (HepG2) cells [73]. Cabello et al. later found that the cytotoxic effects of kinetin riboside stemmed from its ability to induce rapid ATP depletion, creating genotoxic stress which activates p21 and other stress response genes [74]. Furthermore, a research group from the Mayo clinic (USA) identified kinetin riboside from a chemical library screen as the suppressor of cyclin D1 and D2 (CCND1 and CCND2) expression, showing that kinetin riboside could potentially act as a therapeutic agent for multiple myeloma [75].

Besides anti-ageing and anti-cancer effects, kinetin has effective anti-platelet properties, and may be a potential therapeutic agent for treating arterial thrombosis. Kinetin inhibited platelet aggregation in human platelets when stimulated by an agonist [76], and could therefore help to prevent blood clots [77-78].

trans-Zeatin

trans-zeatin was the first naturally-occurring cytokinin identified from a plant source (Zea mays) by Letham [24]. In 1974, Letham identified trans-zeatin in coconut water [79-80], and a year later, van Stadens and Drewes verified the presence of both trans-zeatin and trans-zeatin riboside in coconut water [81]. trans-zeatin riboside is the most abundant type of cytokinin found in coconut water 
(Table 2). trans-zeatin is normally used to induce plantlet regeneration from callus in plant tissue culture. Based on experimental data, trans-zeatin plays a key role in the $\mathrm{G}_{2}-\mathrm{M}$ transition of tobacco cells. It was found to override the blockade of mitosis caused by lovastatin which inhibits cytokinin biosynthesis and controls cellular entry in mitosis [82].

Recent studies showed that trans-zeatin can be a potential drug to treat neural diseases. Some researchers found that trans-zeatin actually possesses an inhibitory effect on acetylcholinesterase and it can be used to treat Alzheimer's disease or related neural dysfunctions, such as dementia [51,52]. Acetylcholinesterase degrades the neural compounds that mediate neural transmission, and thus by blocking its action, synaptic transmission can be improved. Another recent study also found that transzeatin can prevent amyloid $\beta$-protein formation, which has a causal role in the development and progress of Alzheimer's disease [83]. On the other hand, like kinetin, trans-zeatin also exhibited antiageing effects on human fibroblast cells [84].

\subsubsection{Gibberellins (GAs)}

GAs are a class of phytohormones which exert certain effects on plant growth and development, in aspects such as seed germination, epidermal cell elongation, leaf expansion and flower development. The main biological action of GAs is their ability to stimulate the elongation of plant shoots and induce the growth of stems in rosette and dwarfish forms. Together with auxins, GAs stimulate cambial activity and in effect, causing the formation of large xylem and phloem cells in woody plants [85-87]. Apart from the vital roles played in plants, recent study also showed that gibberellin derivatives have anti-tumor bioactivities [88]. Chemically, all known GAs are gibberellic acids (a family of diterpenoids acids), and there are currently 136 members of GAs identified based on their chemical structures. GAs are numbered neither by their structural information nor by their functions, but rather in the order of their identification $[85,87] . \mathrm{GA}_{1}$ and $\mathrm{GA}_{3}$ were successfully detected and quantified in coconut water $[33,89]$.

\subsection{Inorganic ions}

Inorganic ions are required for normal cellular function, and are critical for enzyme activation, bone formation, hemoglobin function, gene expression, and the metabolism of amino acids, lipids and carbohydrates [90-93]. Coconut water contains a variety of inorganic ions (Table 1) [20,29-31] and these ions contribute to the therapeutic value inherent in coconut water. As the basic ion composition of coconut water can replenish the electrolytes of the human body excreted through sweat, such as sodium, potassium, magnesium and calcium, it can serve as an effective rehydration drink [94]. The concentration of these electrolytes in coconut water generates an osmotic pressure similar to that observed in blood [95], and it also does not affect hemostasis (plasma coagulation) [14]. As a result, coconut water can be used as a short term intravenous hydration fluid under certain emergency situations [13]. Interestingly, Anurag and Rajamohan showed that coconut water has cardioprotective effects in experimental myocardial infarction induced in rats and this was probably attributed to the rich content of mineral ions in coconut water, especially potassium [15]. 


\subsection{Vitamins}

Vitamins, which are essential for the normal functioning of the human body, are also found in coconut water. Greater consumption of fruits and vegetables is associated with the reduced risk of cardiovascular disease, stroke, and cancers of the mouth, pharynx, esophagus, lungs, stomach, and colon [96-99], because they contain vitamins and minerals vital for normal physiological functions [86]. Coconut water contains vitamins $\mathrm{B}_{1}, \mathrm{~B}_{2}, \mathrm{~B}_{3}, \mathrm{~B}_{5}, \mathrm{~B}_{6}, \mathrm{~B}_{7}$ and $\mathrm{B}_{9}$ (Table 1). The $\mathrm{B}$ vitamins are water-soluble and are required as coenzymes for enzymatic reactions essential for cellular function [100].

Vitamin $\mathrm{B}_{6}$ (which includes pyridoxal, pyridoxine and pyridoxamine) serves as a coenzyme in various enzymatic reactions, such as the transamination and decarboxylation reactions [101]. For example, it is the coenzyme of $\gamma$-cystathionase [102], which catalyses the cleavage of cystathionine, releasing $\alpha$-ketobutyrate and cystein [103]. The $\alpha$-ketobutyrate molecule is subsequently converted into succinyl-CoA and fed to the tricarboxylic acid (TCA) cycle while cystein is involved in protein and gluthathione biosynthesis [104-105]. Vitamin $\mathrm{B}_{6}$ deficiency can affect various processes of the body, such as inflammation and renal function [100].

Coconut water contains folate (Table 1), also known as vitamin $\mathrm{B}_{9}$. It was identified in the late 1930's as the nutrient required to reduce anemia during pregnancy [106]. It can prevent mitochondrial toxicity induced by methanol metabolites. In addition, the active form of folate, 5-methyltetrahydrofolate is believed to be one of the central methyl donors required for mitochondrial protein and nucleic acid synthesis [28]. Lower blood levels of vitamin $\mathrm{B}_{6}$ and folate can increase the risk for atherosclerosis and other vascular diseases [107]. Another study found that high plasma levels of vitamin $\mathrm{B}_{6}$ and folate may reduce the risk for breast cancer [108]. In addition to vitamin $\mathrm{B}$, coconut water also contains vitamin $\mathrm{C}$ (total ascorbic acid, Table 1), which is an important dietary antioxidant $[28,63]$.

\section{Conclusions}

Coconut water, being a refreshing beverage, provides important health benefits. The chemical components which contribute to its bioactivity are essential to the plant industry, biotechnology and biomedical fields. Undoubtedly, cytokinins are currently the most important components in coconut water. Significant advances were made in understanding the biological functions of the various cytokinins in both plant and human systems. The potential anti-cancer properties of specific cytokinins could bring encouraging and novel perspectives in finding cures for the different types of cancers. The recent discovery of other medicinal values of coconut water signifies a good potential in improving human health. Better insights and understanding of the functions and properties of the individual components of coconut water will, therefore, help us to better utilise this marvellous and multidimensional liquid with special biological properties from nature.

\section{Future Studies}

The chemical composition of coconut water is affected by several factors. Jackson et al. showed that coconut water of different coconut varieties contains different concentration of compounds, and 
that the chemical contents also varied during the different stages of maturity [109]. Soil and environmental conditions also affect the chemical profile of coconut water. A study which was done in Brazil demonstrated that the physical properties of coconut water were affected by varying nitrogen and potassium application [110]. Hence, future studies should be carried out to determine the factors that produce the desirable chemical composition for a specific purpose. Breeding studies can also be carried out to produce coconut water enriched with specific chemical compounds.

Although coconut water is already well studied in terms of its chemical content, there may still be unknown solutes which contribute to its special biological effects. With the development of more advanced detection techniques, screening can be intensified to detect novel compounds of medicinal values present in coconut water.

\section{Acknowledgements}

We would like to thank Stuart Letham (Australian National University) for sharing with us his idea in Canberra that there are a lot of "good biochemicals and especially cytokinins" in coconut water and that we will discover potentially novel biochemicals in these marvellous tropical fruits especially with the technological advancement in analytical tools.

\section{References}

1. Lopes, M.A.; Larkins B.A. Endosperm origin, development and function. Plant cell 1993, 5, 1383-1399.

2. Janick, J.; Paull, R.E. The Encyclopedia of Fruit \& Nuts; CAB International: Wallingford, UK, 2008; p. 112.

3. Patrick, J.W.; Offler, C.E. Compartmentation of transport and transfer events in developing seeds. J. Exp. Bot. 2001, 52, 551-564.

4. Kobayashi, H.; Morisaki, N.; Tago, Y.; Hashimoto, Y.; Iwasaki, S.; Kawachi, E.; Nagata, R.; Shudo, K. Structural identification of a major cytokinin in coconut milk as $14-O-(3-O-[\beta-\mathrm{D}-$ galactopyranosyl-(1-->2)- $\alpha$-D-galactopyranosyl-(1-->3)- $\alpha$-L-arabinofuranosyl]-4-O-( $\alpha$-L-arabinofuranosyl)- $\beta$-D-galactopyranosyl)-trans-zeatin riboside. Chem. Pharm. Bull. 1997, 45, 260-264.

5. Sandhya, V.G.; Rajamohan, T. Comparative evaluation of the hypolipidemic effects of coconut water and lovastatin in rats fed fat-cholesterol enriched diet. Food Chem. Toxicol. 2008, 45, 3585-3592.

6. Asian and Pacific Coconut Community (APCC). International Codes and Standard for Aqueous Coconut Products, 2nd draft. Standards Task Force, Asian and Pacific Coconut Community: Jakarta, Indonesia, 1994.

7. Seow, C.C.; Gwee, C.N. Coconut milk: Chemistry and technology. Int. J. Food Sci. Tech. 1997, 32, 189-201.

8. George, E.F.; Sherrington, P.D. Plant Propagation by Tissue Culture-Handbook and Directory of Commercial Laboratories; Exegetics Ltd: Edington, UK, 1984.

9. Mariat, F. Influence du lait du coco et du coprah sur le de'velopement de jeunes plantules de Cattleya. Bull. Soc. Bot. Fr. 1951, 98, 260-263. 
10. Mauney, J.R.; Hillman, W.S.; Miller, C.O.; Skoog, F; Clayton, R.A.; Strong, F.M. Bioassay, purification and properties of a growth factor from coconut. Physiol. Plant. 1952, 5, 485-497.

11. Shaw, M.; Srivastava, B.I.S. Purine-Like substances from coconut endosperm and their effect on senescence in excised cereal leaves. Plant Physiol. 1964, 39, 528-532.

12. Zakaria, Z.A.; Reezal, I.; Mat Jais, A.M.; Somchit, M.N.; Sulaiman, M.R.; Marmin, A.H.I.; Sidek, H.; Husin, S.H.; Rahim, M.H.A.; Abdul Rahman, L. The anti-inflammatory, anti-pyretic and wound healing activities of Cocos nucifera L. (MATAG types) fresh juice and kernel extract in experimental animals. J. Pharmacol. Toxicol. 2006, 1, 516-526.

13. Campbell-Falck, D.; Thomas, T.; Falck, T.M.; Tutuo, N.; Clem, K. The intravenous use of coconut water. Am. J. Emerg. Med. 2000, 18, 108-111.

14. Pummer, S.; Heil, P.; Maleck, W.; Petroianu, G. Influence of coconut water on hemostasis. Am. J. Emerg. Med. 2001, 19, 287-289.

15. Anurag, P.; Rajamohan, T. Cardioprotective effect of tender coconut water in experimental myocardial infarction. Plant Foods. Hum. Nutr. 2003, 58, 1-12.

16. Alleyne, T.; Roache, S.; Thomas, C.; Shirley, A. The control of hypertension by use of coconut water and mauby: Two tropical food drinks. West Indian Med. J. 2005, 54, 3-8.

17. van Overbeek, J.; Conklin, M.E.; Blakeslee, A.F. Factors in coconut milk essential for growth and development of very young Datura embryos. Science 1941, 94, 350-351.

18. Verdeil, J.L.; Hocher, V. Digestion and absorption of food in plants: A plant stomach Trends Plant Sci. 2002, 7, 280-281.

19. Ang, S.L.P; Yong, J.W.H. A protocol for in vitro germination and sustainable growth of two tropical mistletoes. Plant Cell Tiss. Org. Cult. 2005, 80, 221-228.

20. Arditti, J. Micropropagation of Orchids, 2nd ed.; Blackwell Publishing: Oxford, UK, 2008; Volume II.

21. Kende, H.; Zeevaart. J. The five "Classical" plant hormones. Plant Cell 1997, 9, 1197-1210.

22. Miller, C.O.; Skoog, F.; Von Saltza, M.H.; Strong, F.M. Kinetin, a cell division factor from deoxyribonucleic acid. J. Am. Chem. Soc. 1955, 77, 1392-1393.

23. Miller, C.O.; Skoog, F.; Okumura, F.S.; von Saltza, M.H.; Strong, F.M. Isolation, structure and synthesis of kinetin, a substance promoting cell division. J. Am. Chem. Soc. 1956, 78, 1375-1380.

24. Letham, D.S. Zeatin, a factor inducing cell division isolated from Zea mays. Life Sci. 1963, 2, $569-573$.

25. Vermeulen, K.; Strnad, M.; Kryštof, V.; Havlicek, L.; Van der Aa, A.; Lenjou, M.; Njis, G.; Rodrigus, I.; Stockman, B.; Van Onckelen, H.; Van Bockstaele, D.R.; Berneman, Z.N. Antiproliferative effect of plant cytokinin analogues with an inhibitory activity on cyclindependent kinases. Leukemia 2002, 16, 299-305.

26. Rattan, S.I.S.; Clark, B.F.C. Kinetin delays the onset of ageing characteristics in human fibroblasts. Biochem. Biophys. Res. Commun. 1994, 201, 665-672.

27. Evans, P.; Halliwell, B. Micronutrients: Oxidant/antioxidant Status. Br. J. Nutr. 2001, 85, S67-S74.

28. Shenkin, A. The key role of micronutrients. Clinical Nutr. 2006, 25, 1-13. 
29. Tulecke, W.; Weinstein, L.; Rutner, A.; Laurencot, H. The biochemical composition of coconut water (coconut milk) as related to its use in plant tissue culture. Contrib. Boyce Thompson Inst. 1961, 21, 115-128.

30. Santoso, U.; Kubo, K.; Ota, T.; Tadokoro, T.; Maekawa, A. Nutrient composition of kopyor coconuts (Cocos nucifera L.). Food Chem. 1996, 57, 299-304.

31. United States Department of Agriculture (USDA). National Nutrient Database for Standard Reference, 2008. Nuts, coconut water [Online]. Available: http:/www.nal.usda.gov/fnic/ foodcomp/cgi-bin/list_nut_edit.pl/, accessed on 9 December 2009.

32. Ge, L.; Tan, S.; Yong, J.W. H.; Tan, S.N. Capillary electrophoresis for cytokinin analyses: A review. Electrophoresis 2006, 27, 4779-4791.

33. Ge, L.; Peh, C.Y.C.; Yong, J.W.H.; Tan, S.N.; Hua, L.; Ong, E.S. Analyses of gibberellins by capillary electrophoresis-mass spectrometry combined with solid-phase extraction. $J$. Chromatogr. A 2007, 1159, 242-249.

34. Ma, Z.; Ge, L.; Lee, A.S.Y.; Yong, J.W.H.; Tan, S.N.; Ong, E.S. Simultaneous analysis of different classes of phytohormones in coconut (Cocos nucifera L.) water using high-performance liquid chromatography and liquid chromatography-tandem mass spectrometry after solid-phase extraction, Anal. Chim. Acta 2008, 610, 274-281.

35. Wu, Y.; Hu, B. Simultaneous determination of several phytohormones in natural coconut juice by hollow fiber-based liquid-liquid-liquid microextraction-high performance liquid chromatography, J. Chromatogr. A 2009, 1216, 7657-7663.

36. Blakeslee, J.J.; Peer, W.A.; Murphy, A.S. Auxin transport. Curr. Opin. Plant Bio. 2005, 8, 494-500.

37. Bialek, L.; Michalczuk, L.; Cohen, J.D. Auxin biosynthesis during seed germination in Phaseolus vulgaris. Plant Physiol. 1992, 100, 509-517.

38. Jakubowska, A.; Kowalczyk, S. A specific enzyme hydrolyzing 6- $O(4-O)$-indole-3-ylacetyl- $\beta$-dglucose in immature kernels of Zea mays. J. Plant Physiol. 2005, 162, 207-213.

39. Berleth, T.; Krogan, N.T.; Scarpella, E. Auxin signals - turning genes on and turning cells around. Curr. Opin. Plant Bio. 2004, 7, 553-563.

40. Dharmasiri, N.; Dharmasiri, S.; Weijers, D.; Lechner, E.; Yamada, M.; Hobbie, L.; Ehrismann, J.S.; Jurgens, G.; Estelle, M. Plant development is regulated by a family of auxin receptor F Box proteins. Dev. Cell 2005, 9, 109-119.

41. Robert, H.S.; Friml, J. Auxin and other signals on the move in plants. Nat. Chem. Biol. 2009, 5, 325-332.

42. Werner, T.; Motyka, V.; Strnad, M.; Schmulling, T. Regulation of plant growth by cytokinin. Proc. Natl. Acad. Sci. USA 2001, 98, 10487-10492.

43. Amasino, R.M. 1955: Kinetin arrives. The $50^{\text {th }}$ anniversary of a new plant hormone. Plant Physiol. 2005, 138, 1177-1184.

44. Mok, D.W.S.; Mok, M.C. Cytokinins: Chemistry, Activity and Function; CRC Press: Boca Raton, FL, USA, 1994.

45. Tantikanjana, T.; Yong, J.W.H.; Letham, D.S.; Griffith, M.; Hussain, H.; Ljung, K.; Sandberg, G.; Sundaresan, V. Control of axillary bud initiation and shoot architecture in Arabidopsis by the SUPERSHOOT gene. Genes Dev. 2001, 15, 1577-1588. 
46. Haberer, G.; Kieber, J.J. Cytokinins. New insights into a classic phytohormone. Plant Physiol. 2002, 128, 354-362.

47. Frank, M.; Schmulling, T. Cytokinin cycles cells. Trends Plant Sci. 1999, 4, 243-244.

48. Gan, S.; Amasino, R.M. Cytokinins in plant senescence: From spray and pray to clone and play. Bioessays 1996, 18, 557-565.

49. Huan, L.V.T.; Takamura, T.; Tanaka M. Callus formation and plant regeneration from callus through somatic embryo structures in Cymbidium orchid. Plant Sci. 2004, 166, 1443-1449.

50. Choi, B.H.; Kim, W.; Wang, Q.C.; Kim, D.C.; Tan, S.N.; Yong, J.W.H.; Kim, K.T.; Yoon, H.S. Kinetin riboside preferentially induces apoptosis by modulating Bcl-2 family proteins and caspase-3 in cancer cells. Cancer Lett. 2008, 261, 37-45.

51. Heo, H.J.; Hong, S.C.; Cho, H.Y.; Hong, B.; Kim, H.K.; Kim, E.K.; Shin, D.H. Inhibitory effect of zeatin, isolated from Fiatoua villosa, on acetylcholinesterase activity from PC12 cells. Mol. Cells 2002, 13, 113-117.

52. Kim, M.J.; Choi, S.J.; Lim, S.T.; Kim, H.K.; Kim, Y.J.; Yoon, H.G.; Shin, D.H. Zeatin supplement improves scopolamine-induced memory impairment in mice. Biosci. Biotechnol. Biochem. 2008, 72, 577-581.

53. Barciszewski, J.; Siboska, G.E.; Pedersen, B.O.; Clark, B.F.; Rattan, S.I. Evidence for the presence of kinetin in DNA and cell extracts. FEBS Lett. 1996, 393, 197-200.

54. Ge, L.; Yong, J.W.H.; Goh, N.K.; Chia, L.S.; Tan, S.N.; Ong, E.S. Identification of kinetin and kinetin riboside in coconut (Cocos nucifera L.) water using a combined approach of liquid chromatography-tandem mass spectrometry, high performance liquid chromatography and capillary electrophoresis. J. Chromatogr. B 2005, 829, 26-34.

55. Sobieszczuk-Nowicka, E.; Wieczorek, P.; Legocka, J. Kinetin affects the level of chloroplast polyamines and transglutaminase activity during senescence of barley leaves. Acta Biochim. Pol. 2009, 56, 255-259.

56. Letham, D.S.; Palni, L.M.S. The biosynthesis and metabolism of cytokinins. Annu. Rev. Plant Physiol. Plant Mol. Biol. 1983, 34, 163-197.

57. Kaminek, M. Progress in cytokinin research. Trends Biotechnol. 1992, 10, 159-164.

58. Binns, A.N. Cytokinin accumulation and action: biochemical, genetic and molecular approaches. Annu. Rev. Plant Physiol. Plant Mol. Biol. 1994, 45, 173-196.

59. Sharma, S.P.; Kaur, P.; Rattan, S.I.S. Plant growth hormone kinetin delays aging, prolongs the life span and slows down development of the fruitfly Zapronius paravittiger. Biochem. Biophys. Res. Commun. 1995, 216, 1067-1071.

60. Sharma, S.P.; Kaur, J.; Rattan, S.I.S. Increased longevity of kinetin-fed Zapronius fruitflies is accompanied by their reduced fecundity and enhanced catalase activity. Biochem. Mol. Biol. Int. 1997, 41, 869-875.

61. Lee, J.H.; Chung, K.Y.; Bang, D.; Lee, K.H. Searching for aging-related proteins in human dermal microvascular endothelial cells treated with anti-aging agents. Proteomics 2006, 6, 1351-1361.

62. Minorsky, P.V. The hot and the classic. Kinetin: The elixir of life? Plant Physiol. 2003, 132, $1135-1136$. 
63. Rattan, S.I.S. Method and composition for ameliorating the adverse effects of aging. US Pat. 5371089, 1994.

64. McCullough, J.L.; Weinstein, G.D. Clinical study of safety and efficacy of using topical kinetin 0.1\% (Kinerase R) to treat photodamaged skin. Cosmetic Dermatol. 2002, 15, 29-32.

65. Collins, A.R.; Oxidative DNA damage, antioxidants and cancer. BioEssays 1999, 21, 238-246.

66. Olsen, A.; Siboska, G.E.; Clark, B.F.C.; Rattan, S.I.S. $N^{6}$-Furfuryladenine, kinetin, protects against Fenton reaction-mediated oxidative damage to DNA. Biochem. Biophys. Res. Commun. 1999, 265, 499-502.

67. Verbeke, P.; Siboska, G.E.; Clark, B.F.C.; Rattan, S.I.S. Kinetin inhibits protein oxidation and glycoxidation in vitro. Biochem. Biophys. Res. Commun. 2000, 276, 1265-1270.

68. Leshem, Y.Y. Plant senescence processes and free radicals. Free Radical Biol. Med. 1988, 5, $39-49$.

69. Griffaut, B.; Bos, R.; Maurizis, J.C.; Madelmont, J.C.; Ledoigt, G. Cytotoxic effects of kinetin riboside on mouse, human and plant tumour cells. Int. J. Biol. Marcomol. 2004, 34, 271-275.

70. Orr, M.F.; McSwain, B. The effect of kinetin upon epithelium and fibroblasts in tissue culture. Cancer 1957, 10, 617-624.

71. Orr, M.F.; McSwain, B. The effect of kinetin, kinetin ribofuranoside and gibberellic acid upon cultures of skin and mammary carcinoma and cystic disease. Cancer Res. 1960, 20, 1362-1364.

72. Kowalska, E. Influence of kinetin (6-furfurylo-amino-purine) on human fibroblasts in the cell culture. Folia Morphol. 1992, 51, 109-118.

73. Cheong, J.; Goh, D.; Yong, J.W.H.; Tan, S.N.; Ong, E.S. Inhibitory effect of kinetin riboside in human heptamoa, HepG2. Mol. BioSyst. 2009, 5, 91-98.

74. Cabello, C.M.; Bair, W.B. III; Ley, S.; Lamore, S.D.; Azimian, S.; Wondrak, G.T. The experimental chemotherapeutic $N^{6}$-furfuryladenosine (kinetin-riboside) induces rapid ATP depletion, genotoxic stress, and CDKN1A (p21) upregulation in human cancer cell lines. Biochem. Pharmacol. 2009, 77, 1125-1138.

75. Tiedemann, R.E.; Mao, X.; Shi, C.X.; Zhu, Y.X.; Palmer, S.E.; Sebag, M.; Marler, R.; Chesi, M.; Fonseca, R.; Bergsagel, P.L.; Schimmer, A.D.; Stewart, A.K. Identification of kinetin riboside as a repressor of CCND1 and CCND2 with preclinical antimyeloma activity. J. Clin. Invest. 2008, 118, 1750-1764.

76. Sheu, J.R.; Hsiao, G.; Shen, M.Y.; Chou, C.Y.; Lin, C.H.; Chen, T.F.; Chou, D.S. Inhibitory mechanisms of kinetin, a plant growth-promoting hormone, in platelet aggregation. Platelets 2003, 14, 189-196.

77. Hsiao, G.; Shen M.Y.; Lin, K.H.; Chou C.Y.; Tzu, N.H.; Lin, C.H.; Chou, D.S.; Chen, T.F.; Sheu, J.R. Inhibitory activity of kinetin on free redical formation of activated platelets in vitro and on thrombus formation in vivo. Eur. J. Pharmacol. 2003, 465, 281-287.

78. Barciszewski, J.; Massino, F.; Clark, B.F.C. Kinetin- a multiactive molecule. Int. J. Biol. Macromol. 2007, 40, 182-192.

79. Letham, D.S. Regulators of cell division in plant tissues. XX. The cytokinins of coconut milk. Physiol. Plant. 1974, 32, 66-70.

80. Letham, D.S. Regulators of cell division in plant tissues. XXI. Distribution of coefficients for cytokinins. Planta 1974, 118, 361-364. 
81. Van Staden, J.; Drewes, S.E. Identification of zeatin and zeatin riboside in coconut milk. Physiol. Plant. 1975, 34, 106-109.

82. Laureys, F.; Dewitte, W.; Witters, E.; Van Montagu, M.; Inzé, D.; Van Onckelen, H. Zeatin is indispensable for the G2-M transition in tobacco BY-2 cells. FEBS lett. 1998, 426, 29-32.

83. Choi, S.J.; Jeong, C.H.; Choi, S.G.; Chun, J.Y.; Kim, Y.J.; Lee, J.M.; Shin, D.H.; Heo, H.J. Zeatin prevents amyloid beta-induced neurotoxicity and scopolamine-induced cognitive deficits. $J$. Med. Food 2009, 12, 271-277.

84. Rattan, S.I.S.; Sodagam, L. Gerontomodulatory and youth-preserving effects of zeatin on human skin fibroblasts undergoing aging in vitro. Rejuvenation Res. 2005, 8, $46-57$.

85. Buchanan, B.B.; Gruissem, W.; Jones, R.L. Biochemistry \& Molecular Biology of Plants. In American Society of Plant Physiologists; John Wiley \& Sons, Inc.: Sommerset, NJ, USA, 2000.

86. Tucker, G.A., Roberts, J.A. Plant Hormone Protocols; Humana Press Inc.: Totowa, NJ, USA, 2000.

87. Davies, P.J. Plant Hormones: Biosynthesis, Signal Transduction, Action!; Kluwer Academic: Dordrecht, The Netherlands, 2004.

88. Chen., J.; Sun, Z.; Zhang, Y.; Zeng, X.; Qing, C.; Liu, J.; Li, L.; Zhang, H. Synthesis of gibberellin derivatives with anti-tumor bioactivities. Bioorg. Med. Chem. Lett. 2009, 19, 5496-5499.

89. Ge, L.; Yong, J.W.H.; Tan, S.N.; Hua, L.; Ong, E.S. Analyses of gibberellins in coconut (Cocos nucifera L.) water by partial filling - micellar electrokinetic chromatography - mass spectrometry with reversal of electroosmotic flow. Electrophoresis 2008, 29, 2126-2134.

90. Institute of Medicine (IOM), Dietary Reference Intakes for Calcium, Phosphorus, Magnesium, Vitamin D, and Fluoride; National Academy Press: Washington, DC, USA, 2000.

91. Institute of Medicine (IOM), Dietary Reference Intakes for Vitamin C, Vitamin E, Selenium, and Carotenoids; National Academy Press: Washington, DC, USA, 2000.

92. Institute of Medicine (IOM), Dietary Reference Intakes for Vitamin A, Vitamin K, Arsenic, Boron, Chromium, Copper, Iodine, Iron, Manganese, Molybdenum, Nickel, Silicon, Vanadium, and Zinc; National Academy Press: Washington, DC, USA, 2001.

93. Wall, M.M. Ascorbic acid and mineral composition of longan (Dimocarpus longan), lychee (Litchi chinensis) and rambutan (Nephelium lappaceum) cultivars grown in Hawaii. J. Food Compost. Anal. 2006, 19, 655-663.

94. Saat, M.; Singh, R.; Sirisinghe, R.G.; Nawawi, M. Rehydration after exercise with fresh young coconut water, carbohydrate-electrolyte beverage and plain water. J. Physiol. Anthropol. Appl. Human Sci. 2002, 21, 93-104.

95. Fernandes, J.C.B.; Neto, O.G.; Rohwedder, J.J.R.; Kubota, L.T. Simultaneous determination of chloride and potassium in carbohydrate electrolyte beverages using in array of ion-selective electrodes controlled by a microcomputer. J. Brazilian Chem. Soc. 2000, 11, 349-354.

96. Gillman, M.W.; Cupples, L.A.; Gagnon, D.; Posner, B.M.; Ellison, R.C.; Castelli, W.P.; Wolf, P.A. Protective effect of fruits and vegetables on development of stroke in men. J. Am. Med. Assoc. 1995, 273, 1113-1117. 
97. Joshipura, K.J.; Hu, F.B.; Manson, J.E.; Stampfer, M.J.; Rimm, E.B.; Speizer, F.E.; Colditz, G.; Ascherio, A.; Rosner, B.; Spiegelman, D.; Willett, W.C. The effect of fruit and vegetable intake on risk for coronary heart disease. Ann. Intern. Med. 2001, 134, 1106-1114.

98. Bazzano, L.A.; He, J.; Ogden, L.G.; Loria, C.M.; Vupputuri, S.; Myers, L.; Whelton, P.K. Fruit and vegetable intake and risk of cardiovascular disease in US adults: The first national health and nutrition examination survey epidemiologic follow-up study. Am. J. Clin. Nutr. 2002, 76, 93-99.

99. Riboli, E.; Norat, T. Epidemiologic evidence of the protective effect of fruit and vegetables on cancer risk, Am. J. Clin. Nutr. 2003, 78, 559-569.

100. Depeint, F.; Bruce, W.R.; Shangari, N.; Mehta, R.; O'Brien, P.J. Mitochondrial function and toxicity: Role of B vitamins on the one-carbon transfer pathways. Chem. Biol. Interact. 2006, 163, 113-132.

101. Garrett, R.H.; Grisham, G.M. Biochemistry, 3rd ed.; Thomson Brooks/Cole: Belmont, CA, USA, 2005.

102. Matsuo, Y.; Greenberg, D.M. A crystalline enzyme that cleaves homoserine and cystathionine: III. Coenzyme resolution, activators, and inhibitors. J. Biol. Chem. 1958, 234, 507-515.

103. Carroll, W.R.; Stacy, G.W.; du Vigneaud, V. $\alpha$-Ketobutyric acid as a product in the enzymetic cleavage of cystathionine. J. Biol. Chem. 1949, 180, 375-382.

104. Conn, E.E.; Stumpf, P.K. Outlines of Biochemistry, 3rd ed.; John Wiley \& Sons, Inc.: New York, NY, USA, 1972; pp. 436-437.

105. Lieberman, M.; Marks, A.D.; Smith, C. Mark's Essentials of Medical Biochemistry. A Clinical Approach; Lippincott Williams \& Wilkins: Baltimore, MD, USA, 2007.

106. Goh, Y.I.; Koren, G. Folic acid in pregnancy and fetal outcomes. J. Obstet. Gynaecol. 2008, 28, $3-13$.

107. Robinson, K.; Arheart, K.; Refsum, H.; Brattström, L.; Boers, G.; Ueland, P.; Rubba, P.; PalmaReis, R.; Meleady, R.; Daly, L.; Witteman, J.; Graham I. Low circulating folate and vitamin B6 concentrations: Risk factors for stroke, peripheral vascular disease, and coronary artery disease. Circulation 1998, 97, 437-443.

108. Zhang, S.M.; Willett, W.C.; Selhub, J.; Hunter, D.J.; Giovannucci, E.L.; Holmes, M.D.; Colditz, G.A.; Hankinson, S.E. Plasma folate, vitamin B6, vitamin B12, homocysteine, and risk of breast cancer. J. Natl. Cancer Inst. 2003, 95, 373-380.

109. Jackson, J.C.; Gordon, A.; Wizzard, G.; McCook, K.; Rolle, R. Changes in chemical composition of coconut (Cocos nucifera L.) water during maturation of the fruit. J. Sci. Food Agri. 2004, 84, 1049-1052.

110. Neto, M.F.; de Holanda, J.S.; Folegatti, M.V.; Gheyi, H.R.; Pereira, W.E.; Cavalcante, L.F. Quality of green fruits of "anão verde" coconut in relation to doses of nitrogen and potassium via fertigation. Rev. Bras. Eng. Agríc. Ambient. 2007, 11, 453-458.

Sample Availability: Not Available.

(C) 2009 by the authors; licensee Molecular Diversity Preservation International, Basel, Switzerland. This article is an open-access article distributed under the terms and conditions of the Creative Commons Attribution license (http://creativecommons.org/licenses/by/3.0/). 